\title{
EFFECT OF MANURE PLUS AND INORGANIC FERTILIZER ON MAIZE PRODUCTION AND NUTRIENT UPTAKE IN CENTRAL JAVA INDONESIA
}

\author{
Dwi Retno Lukiwati*, Florentina Kusmiyati and Bagus Herwibawa \\ Faculty of Animal and Agricultural Sciences, Diponegoro University, Semarang, Indonesia
}

\begin{abstract}
Maize is used by farmer under crop-livestock integrated farming system (CLIFS) in Indonesia. The characteristic of CLIFS is crop yield for food, stover for feed, cattle dung for manure as organic fertilizer. The quality of manure could be increased by adding organic phosphorus (guano, rock phosphate/RP) at initial phase of decomposition process. This research was aimed to improve manure quality by adding organic P (RP, guano) that was called as manure plus, then to evaluate manure plus and inorganic fertilizer on maize production, dry matter (DM) production and nutrient uptake of stover. Chemical properties of manure, manure plus and nutrient of stover were evaluated at the laboratory and field experiment with 6 treatments of fertilization and five replicates at latosolic soil. The treatments were $(\mathrm{TSP}+\mathrm{SA}+\mathrm{KCl})$, manure+ $(\mathrm{TSP}+\mathrm{SA}+\mathrm{KCl})$, manure+ $(\mathrm{RP}+\mathrm{SA}+\mathrm{KCl})$, manure+ (guano+SA+KCl), (RP-manure) $+\mathrm{SA}+\mathrm{KCl}$ and (guano-manure) $+\mathrm{SA}+\mathrm{KCl}$. The maize was harvested at 11 weeks after planting. Parameter measured were maize production, DM production and nutrient uptake of stover. The result showed that the chemical properties of manure plus was varied. RP-manure was higher in P (3.26\%) and K (3.10\%) compared to manure and guano-manure. Guanomanure was higher in $\mathrm{N}(1.66 \%)$ compared to manure and RP-manure. However, the effect of all the treatment was no significantly different on maize production, DM production and nutrient uptake of stover, except on $\mathrm{N}$ uptake of stover. It was concluded that manure plus replaces TSP as inorganic fertilizer.
\end{abstract}

Keywords: Guano, manure, nutrient, rock phosphate, waxy-corn

\section{Introduction}

Waxy-corn (Zea mays ceratina L.) is a variety of maize with a high amylopectin content $90 \%$ and has highly green fodder production that has a real interest to livestock feed (Ramansyah et al. 2013). Waxy-corn is used by farmer under crop-livestock integrated farming system (CLIFS) in Indonesia especially in Central Java. The characteristic of CLIFS is crop yield for food, stover for ruminant feed and cattle dung for manure as organic fertilizer. The use of organic fertilizers made up of various composted materials, is now established as a key strategy not only for improving soil organic matter contents and nutrient supply to plant but also for reducing the input cost of mineral fertilizers and promoting healthier environments (Ahmad et al. 2006). Use of organic manures alongside inorganic fertilizers often lead to increased soil organic matter (SOM), soil structure, water holding capacity and improved nutrient cycling and helps to maintain soil nutrient status, cation exchange capacity (CEC) and soil's biological activity (Saha et al., 2008).

Phosphorus is a major plant nutrient and considered one of the primary factors limiting crops yield (Zaidi et al., 2009). Phosphorus is needed for growth, utilization of sugar and starch, photosynthesis, metabolic process which leads to higher yield potential (Ayub et al. 2002). Therefore, application of $P$ fertilizers is essentially required to improve crop yield. Manure in general low in most of major nutrients, and organic phosphorus (rock phosphate, guano) can advantageously compensate the imbalance of manure on P nutrients (Ramilison, 2001). The quality of manure could be increased by adding organic phosphorus sources (RP, guano) at initial phase of decomposition process (Lukiwati et al. 2014). Main problem in using the nature-P (organic-P) is to solubilize and enhance availability of $\mathrm{P}$ content (Khan et al. 2009). However, if natural $\mathrm{P}$ is allowed to react with organic acids produced during composting, a major part of natural P could be solubilized for plant uptake (Singh and Reddy, 2011). It is well documented that during composting process of organic waste a variety of organic acids are released. The extent of nature- $\mathrm{P}$ solubilization by composting material depend on many factors such as type of nature $\mathrm{P}$ fertilizer 
Deposits of nature P (RP, guano) in Indonesia such as Cirebon District (West Java), Pati District (Central Java) and Gresik District (East Java). Guano is decomposed bat manure. Desert bat manure guano escapes leaching in caves, preserving its nutrients (Wireko-Manu and Amamoo, 2017). Meanwhile, rock phosphate a naturally occurring mineral source of insoluble phosphate, and the solubility can be increased by organic acids is the major advantage of composting through (Imran et al. 2011; Qureshi et al. 2014). Effectiveness of organic-P fertilizers was enhanced by presence of NK fertilizer as well (Ramilison, 2001). An integrated use of inorganic fertilizers with organic manure is a sustainable approach for efficient nutrient usage which enhances efficiency of the chemical fertilizers while reducing nutrient losses to improve crop productivity on sustainable basis (Schoebitz and Vidal, 2016; Mahmood et al. 2017). Keeping all these aspects in consideration, the present study was therefore conducted to evaluate the effect of manure plus (organic P-enriched manure) and inorganic fertilizer on waxycorn production, DM production and nutrient uptake of stover.

\section{Materials and Methods}

\section{Phosphorus-enriched manure and inorganic fertilizers as treatment}

The materials used were cow dung collected from local farmer, RP and guano collected from the community mining in Pati District of Central Java. All of its material for the formulation of organic P-enriched manure (PEM). Organic-P such as RP and guano $\left(66 \mathrm{~kg} \mathrm{P} \mathrm{ha}^{-1}\right)$ and cow dung $\left(20 \mathrm{t} \mathrm{ha}^{-1}\right)$ were mixed and added effective microorganism (EM) and water then composted anaerobically for 6 weeks and called manure plus. Meanwhile the manure was made from cow dung mixed with EM and water only and then composted anaerobically for 6 weeks as well. After composting for 6 weeks only the manure could use as organic fertilizer, with or without enriched with organic-P. Random samples of manure (M), P-RP enriched manure (RP-EM) and P-guano enriched manure (guano-EM) were collected from the bulks separately, air-dried, ground, sieved and then analyzed for total organic matter $(\mathrm{OM})$, organic $\mathrm{C}(\mathrm{OC})$, total $\mathrm{N}$, total $\mathrm{P}$, total $\mathrm{K}$ and $\mathrm{C}: \mathrm{N}$ ratio. Composition of organic manures used in the experiment is given in Table 1. Sulphate ammonium (SA), TSP and $\mathrm{KCl}$ were used as inorganic sources at $200 \mathrm{~kg} \mathrm{~N} \mathrm{ha}^{-1}, 66 \mathrm{~kg} \mathrm{ha}^{-1}$ and $125 \mathrm{~kg} \mathrm{~K} \mathrm{ha}^{-1}$, respectively. Following treatments were used in this experiment $\mathrm{T} 1 .(\mathrm{TSP}+\mathrm{SA}+\mathrm{KCl}), \mathrm{T} 2$. Manure+(TSP+SA+KCl$), \mathrm{T} 3$. Manure+(RP+SA+KCl$), \mathrm{T} 4$. Manure $+(\mathrm{guano}+\mathrm{SA}+$ $\mathrm{KCl}), \mathrm{T} 5 .(\mathrm{RP}+$ manure $)+\mathrm{SA}+\mathrm{KCl}$ and $\mathrm{T} 6 .($ guano + manure $)+\mathrm{SA}+\mathrm{KCl}$.

\section{Site description and treatments application}

The experiment of manure plus and inorganic fertilizers treatment above for waxy-corn was conducted on $250 \mathrm{~m}^{2}$ latosolic soil with low pH, N, P and K concentration in Semarang District, Central Java-Indonesia. The soil area was tilled and divided into 30 experimental units and designed as randomized block design with six treatments (T1 to T6) with five replicates. The size of each plot was $2 \mathrm{~m} \mathrm{x} 2 \mathrm{~m}$. In each plot a small holes was made for seed planting so that there were 20 holes per plot and each hole spaced $40 \mathrm{~cm}$ x $50 \mathrm{~cm}$. Organic and inorganic fertilizer were evenly spread onto soil surface by hand and immediately incorporated by tillage before sowing. Tillage was done to $20 \mathrm{~cm}$ depth by shovel and followed by raking. Each plot received basal fertilization of $125 \mathrm{~kg} \mathrm{~K}^{-1}$ as $\mathrm{KCl}$ (Lukiwati et al. 2014), after which fertilization treatment was applied. The next day after the treatment two waxy-corn seed (Zea mays ceratina $\mathrm{L}$ ) was planted into each holes. The maize cobs was harvested 11 weeks after planting, and analyzed for maize cobs production, DM production and nutrient uptake (N, P, Ca) of stover. To measure DM production (DM content in \% $\mathrm{x}$ fresh stover production) the material was chopped, sub-samples and oven-dried to constant weight at $48 \mathrm{~h}$ and weighed. These samples were finally ground and analyzed for N, P and Ca uptake of stover. 


\section{Statistical Analyses}

Waxy-corn cobs production, DM production and nutrient uptake $(\mathrm{N}, \mathrm{P}, \mathrm{Ca})$ of stover were analyzed using one way analyses of variance (ANOVA). When significant differences among the treatments were found $(\mathrm{p}<0.05)$, the data were further tested using Duncan's Multiple Range Test (DMRT).

\section{Results and Discussion}

\section{Chemical analyses}

Chemical analyses result of $\mathrm{P}$-enriched manure fertilizer showed that concentration of $\mathrm{N}, \mathrm{P}$ and $\mathrm{K}$ total of $\mathrm{RP}+$ manure (1.35\%-3.36\%-3.10\%) and guano+manure (1.66\%-1.93\%-2.26\%), respectively. Its P-enriched manure quality was higher compared to manure only in $\mathrm{N}, \mathrm{P}$, and $\mathrm{K}$ total $(0.96 \%-1.35 \%-2.06 \%)$, respectively. Meanwhile, RP+manure quality was higher compared to guano+manure, except $\mathrm{N}$ total (Table 1). Because guano material contain $0.35 \%$ nitrogen as well in this study. Research result in University of Cornell-New York showed that guano contain 3\% N (http://www.css.cornel). It is very likely that during composting of cow dung, organic acids were produced, which solubilized P of RP and P of guano. This may imply that RP+manure can act as excellent source of $\mathrm{P}$ (Imran et al. 2011). RP+manure product proved better than guano+manure product in terms of release of $\mathrm{P}$ (Nishanth and Biswas. 2008).

Table 1 Composition of organic manures used in the experiment

\begin{tabular}{lcccccc}
\hline \multicolumn{1}{c}{ Nutrient source } & $\mathrm{N}(\%)$ & $\mathrm{P}(\%)$ & $\mathrm{K}(\%)$ & $\mathrm{OM}(\%)$ & $\mathrm{OC}(\%)$ & $\mathrm{C} / \mathrm{N}$ \\
\hline Manure & 0.96 & 1.35 & 2.06 & 40.83 & 23.68 & 14.26 \\
\hline RP+manure & 1.35 & 3.26 & 3.10 & 32.33 & 18.75 & 19.53 \\
\hline Guano+manure & 1.66 & 1.93 & 2.26 & 39.42 & 22.86 & 16.93 \\
\hline
\end{tabular}

\section{Waxy-corn cobs production and dry matter production and nutrient uptake of stover}

Result showed that both of the waxy-corn cobs production and DM production of stover were not significantly influenced by the treatments (Table 2). The data summarized in Table 3 showed that Ca uptake and P uptake of waxy-corn stover were not significantly influenced by the treatments as well. All the treatment using $\mathrm{N}, \mathrm{P}$ and $\mathrm{K}$ at the same level $200 \mathrm{~kg} \mathrm{~N} \mathrm{ha}^{-1}, 66 \mathrm{~kg} \mathrm{P} \mathrm{ha}^{-1}$ and $125 \mathrm{~kg} \mathrm{~K} \mathrm{ha}^{-1}$, respectively. This suggested that nutrient value addition with organic P-enriched manure and inorganic-P could provide similar effect on waxy-corn cobs production and DM production (Table 2) and Ca uptake and $\mathrm{P}$ uptake of stover (Table 3). Composting of phosphorus organic (natural $\mathrm{P}$ ) with organic matter converts a part of $\mathrm{P}_{2} \mathrm{O}_{5}$ from PR into available form (Sekhar and Aery, 2001). If natural $P$ is allowed to react with organic acids produced during composting, a major part of natural P could be solubilized for plant uptake (Singh and Reddy, 2011). Similar result reported by Ramilison (2001), effectiveness of P-fertilizers was enhanced by presence of NK fertilizer. Nutrition value of maize stover depends on the types of fertilizers (Wireko-Manu and Amamoo, 2017). The potentially of maize manifested in the form of growth, cobs yield and yield attributes is remarkably affected by various biotic and abiotic factors, of which nutrients management is prime one (Jena et al. 2015).

Table 2 Maize cob and dry matter production with organic and inorganic fertilization

\begin{tabular}{lcc}
\hline \multicolumn{1}{c}{ Treatments } & $\begin{array}{c}\text { Maize cob production } \\
\mathrm{kg} / \mathrm{plot}\end{array}$ & $\begin{array}{c}\text { DM production of } \\
\text { stover (kg/plot) }\end{array}$ \\
\hline $\mathrm{TSP}+\mathrm{SA}+\mathrm{KCl}$ & $9.96 \pm 0.57$ & $12.37 \pm 4.16$ \\
\hline Manure + TSP+SA+KCl & $11.04 \pm 0.68$ & $12.90 \pm 2.94$ \\
\hline Manure + RP+SA+KCl & $9.56 \pm 0.34$ & $11.82 \pm 3.12$ \\
\hline Manure + guano+SA+KCl & $10.04 \pm 0.53$ & $10.57 \pm 3.13$ \\
\hline (RP+manure) $+\mathrm{SA}+\mathrm{KCl}$ & $10.44 \pm 0.41$ & $9.48 \pm 3.36$ \\
\hline (Guano+manure) $+\mathrm{SA}+\mathrm{KCl}$ & $11.20 \pm 0.54$ & $12.41 \pm 2.25$ \\
\hline
\end{tabular}


Table 3 Calcium and phosphorus uptake of maize stover with organic and inorganic fertilization

\begin{tabular}{lcc}
\hline Treatments & $\begin{array}{c}\text { Calcium uptake } \\
\text { g/plot }\end{array}$ & $\begin{array}{c}\text { Phosphorus uptake } \\
\text { g/plot }\end{array}$ \\
\hline TSP+SA+KCl & $44.57 \pm 16.13$ & $62.64 \pm 25.90$ \\
\hline Manure + TSP+SA+KCl & $46.58 \pm 10.61$ & $55.04 \pm 11.78$ \\
\hline Manure+ RP+SA+KCl & $43.50 \pm 10.01$ & $52.68 \pm 14.46$ \\
\hline Manure+ guano+SA+KCl & $42.69 \pm 12.00$ & $50.76 \pm 17.91$ \\
\hline (RP+manure) $+\mathrm{SA}+\mathrm{KCl}$ & $36.50 \pm 11.84$ & $46.38 \pm 17.73$ \\
\hline (Guano+manure) $+\mathrm{SA}+\mathrm{KCl}$ & $54.21 \pm 12.18$ & $60.59 \pm 12.74$ \\
\hline
\end{tabular}

The data of Table 4 showed that $\mathrm{N}$ uptake with (guano+manure)+SA+KCl was significantly higher compared to $\mathrm{TSP}+\mathrm{SA}+\mathrm{KCl}$. Fertilization treatment using N, P and K at the same level of $200 \mathrm{~kg} \mathrm{~N}$ ha-1, $66 \mathrm{~kg}$ P ha-1 and 125 $\mathrm{kg} \mathrm{K}$ ha-1, respectively. However, guano contain $0.35 \%$ nitrogen as well. This suggested that (guano+manure)+SA+KCl could release nitrogen higher compared to $\mathrm{TSP}+\mathrm{SA}+\mathrm{KCl}$, and also enhanced the nitrogen uptake. Manure addition was the best fertilization for improving soil fertility, enhanced soil total nitrogen and soil organic carbon (He et al., 2015). Manure also had a considerable effect on soil microbes and nutrient availability and uptake (Mahmood et al., 2017), and reduced the potential risk of nitrate-N leaching (Wen et al. 2016). Organic manure has more beneficial effects on soil quality than inorganic fertilizers thereby improving nutrient release and their availability to the plants (Birkhofer et al., 2008). As organic fertilizer (guano+manure) is decomposed nutrients are converted into forms that plants can use directly (Magdoff and Van Es, 2009). Thus, the externally applied nitrogen supported native available nitrogen that resulted in higher nitrogen concentration that was sufficient to meet the requirement (Bhatt, 2012).

Table 4 Nitrogen uptake of maize stover with organic and inorganic fertilization

\begin{tabular}{lc}
\hline Treatments & $\begin{array}{c}\text { Nitrogen uptake } \\
\mathrm{kg} / \mathrm{plot}\end{array}$ \\
\hline $\mathrm{TSP}+\mathrm{SA}+\mathrm{KCl}$ & $158.97 \pm 53.93 \mathrm{~b}$ \\
\hline Manure + TSP+SA+KCl & $176.77 \pm 40.79 \mathrm{ab}$ \\
\hline Manure+ RP+SA+KCl & $167.64 \pm 42.92 \mathrm{ab}$ \\
\hline Manure+ guano+SA+KCl & $165.22 \pm 50.68 \mathrm{ab}$ \\
\hline (RP+manure) + SA+KCl & $153.23 \pm 54.23 \mathrm{~b}$ \\
\hline (Guano+manure) $+\mathrm{SA}+\mathrm{KCl}$ & $227.32 \pm 37.18 \mathrm{a}$ \\
\hline
\end{tabular}

Means followed by the same letter for each factor in a column are not different $(\mathrm{P}>0.05)$

\section{Conclusion}

Composting of low grade phosphorus organic (rock phosphate, guano) with organic matter (manure) converts a part of $\mathrm{P}_{2} \mathrm{O}_{5}$ from $\mathrm{PR}$ and guano into available form, and could enhanced the quality of manure, especially $\mathrm{P}$ solubilized for plant uptake. Manure plus or RP+manure and guano+manure resulted in similar on maize cob production and dry matter production and nutrient uptake of stover compared to inorganic fertilizer (TSP). Application of manure plus being locally available is cheaper sources of nutrient availability, and could be an alternative organic fertilizer to replace TSP and reduce cost of crops production as well.

\section{Acknowledgements}

Thanks to University of Diponegoro, Semarang-Indonesia (Grant Research Program 2017) for the support. 


\section{References}

Ahmad, R., Khalid, A., Arshad, M., Zahir, Z.A., and Naveed, M., 2006. Effect of raw (uncomposted) and composted organic waste material on growth and yield of maize (Zea mays L). Soil Environment, 25, 135-142

Ayub, M., Nadeem, M.A., Sharar, M.S., and Mahmood, N., 2002. Response of maize (Zea mays L.) fodder to different levels of nitrogen and phosphorus. Asian Journal of Plant Science. 1: 352-354.

Bhatt, P.S. 2012, Response of sweet corn hybrid to varying plant densities and nitrogen levels, African J. of Agric.Res., 7(46), 6158-6166

Birkhofer, K., Bezemer, T.M., Bloem, J., Bonkows-ki, M., Christensen, S., Dubois, D., Ekelund, F., Fliebach, A., Gunst, L., Hedlund, K., Ma"der, P., Mikola, J., Robin, C., Seta”la, H., Tatin-Froux, F., Van Der Putten, W.H., and Scheu, S., 2008. Long-term organic farming fosters below and aboveground biota: implications for soil quality, biological control and productivity. Soil Biol. Biochem. 40: 2297-2308.

He, Y.T., Zhang, W.J., Xu, M.G., Tong, X.G., Sun, F.X., Wang, J.Z., Huang, S.M., Zhu, P., and He, X.H., 2015. Long-term combined chemical and manure fertilizations increase soil organic carbon and total nitrogen in aggregate fractions at three typical cropland soils in China. Science of the Total Environment 532: 635-644.

Imran, M.R., Waqas, Z.I.H., Nasli, B., Shaharoona and Arshad, M., 2011, Effect of recycled and value-added organic waste on solubilization of rock phosphate in soil and its influence on maize growth. Date of access: 11/07/2017. http:// www.fspublishers.org/

Jena, N., Vani, K.P., Praven Rao, V., and Siva Sankar, A., 2015, Effect of nitrogen and phosphorus fertilizers on growth and yield of quality protein maize (QPM). IJSR 4(12): 197-199.

Khan, A.A., Jilani, G., Akhtar, M.S.,Saqlan, S.M., and Rasheed, M., 2009, Phosphorus solubilizing bacteria: occurrence, mechanisms and their role in crop production. J. Agric. Biol. Sci., 1, 48-58

Lukiwati, D.R., Purbajanti, E.D., and Pujaningsih, R.I., 2014, Sweet corn production and nutritive value of stover with manure enriched with rock phosphate fertilizer and biodecomposer. J.of Agric. Sci. and Tech. A, 4(10), 839842

Magdoff, F. and Van Es, H., 2009, Building Soil for Better Crops. Third Ed. Handbook Series Book 10. SARE Program USDA. Brentwood, M.D

Mahmood, F., Khan, I., Ashraf, U, Shahzad, T., Hussain, S., Shahid, M., Abid, M., and Ullah, S., 2017. Effects of organic and inorganic manures on maize and their residual impact on soil physico-chemical properties. J.of Soil Sci. and Plant Nutrition, 17(1), 22-32

Nishanth, D., and Biswas, D.R., 2008, Kinetics of phosphorus and potassium release from rock phosphate and waste mica enriched compost and their effect on yield and nutrient uptake by wheat Itriticum aestivum). Bioresour. Technol., 99, 3342-3353

Qureshi, S.A., Rajput, A., Memon, M., and Solangi, M.A., 2014, Nutrient composition of rock phosphate enriched compost from various organic waste. E3J.of Sci.Res., 2(3), 47-51

Ramansyah, M., Hidayati, N., Juhaeti, T., and Sugiharto, A.. 2013, Effect of bio-organic fertilizer on productivity improvement of well adapted local maize (Zea mays ceratina L.) variety. ARPN J.of Agroc. And Biol. Sci., 8(3), 233-240

Ramilison, R., 2001, The effect of local rock phosphate fertilizer on yield of maize in P-deficient soils of the Central Plateau of Madagascar. In: Seventh Eastern and Southern Africa Regional Maize Coference. 11-15 February, pp.394-398

Saha, S., Mina, B.L., Gopinath, K.A., Kundu, S., and Gupta, H.S., 2008. Organic amendments affect biochemical properties of a subtemperate soil of the Indian Himalayas. Nutr. Cycl. Agroecosys. 80: 233-242.

Schoebitz, M., and Vidal, G., 2016, Microbial consortium and pig slurry to improve chemical properties of degraded soil and nutrient plant uptake. J.Soil Sci. Plant Nutr., 16(1), 226-236 
Sekhar, D.M.R, and Aery, N.C., 2001. Phosphate rock with farmyard manure as P fertilizer in neutral and weakly alkaline soils. Current Sci. 80(9): 1113 - 1115

Singh, H., and Reddy, M.S., 2011, Effect of inoculation with phosphate solubilizing fungus on growth and nutrient uptake of wheat and maize plants fertilized with rock phosphate in alkaline soils. European J. Soil Biol., 47, 3034

Wen, Z., Shen, J., Blackwell, M., Li, H., Zhao, B., and Yuan, H., 2016, Combined applications of nitrogen and phosphorus fertilizers with manure increase maize yield and nutrient uptake via stimulating root growth in a longterm experiment. Pedosphere, 26(1): 62-73

Wireko-Manu, F.D., and Amamoo, C., 2017, Comparative studies on proximate and some mineral composition of selected local rice varieties and imported ric brands in Ghana. Agric. and Food Sci. Res., 4(1), 1-7.

Zaidi, A., Khan, M.S., Ahemad, M., and Oves, M., 2009, Plant growth promotion by phosphate solubilizing bacteria. Acta Microbiol. Immunol. Hungarica, 56, 263-284 